\title{
Courtroom 6oo: The (Virtual) Reality of Being There
}

\author{
Renske Vos \\ Faculty of Law, Public International Law, Vrije Universiteit Amsterdam, \\ De Boelelaan 1077, 1081 HV Amsterdam, The Netherlands \\ r.n.vos@vu.nl \\ Sofia Stolk \\ T.M.C. Asser Instituut, Dispute Settlement and Adjudication Strand, \\ University of Amsterdam, R.J. Schimmelpennincklaan 20-22, 2517 JN Den \\ Haag, The Netherlands \\ s.stolk@asser.nl
}

\begin{abstract}
Although at least some of the concern with prosecuting aged defendants seems to lie with defendants not quite looking the part, reviews of historic Court buildings come out the other end with allusions to eminence, authenticity, tradition, history and gravitas. Exemplary is the Courtroom 6oo Project, a VR experience of the Nuremberg Trials set in a virtual rendition of the Palace of Justice in Nuremberg. Courtroom 6 oo remains today one of the major material referents in the histories of international law, representing the symbolic birthplace of International Criminal Law. The attraction of the Court moreover is such that the building has come to offer, as we would say, a legal sightseeing point of interest. In this piece, we pick up on the Courtroom 6oo Project as capitalising on the interest with visiting the place 'where it happened', and pushing the boundaries of experiencing 'being there', where it happened.
\end{abstract}

\section{Keywords}

international law - international criminal law - Nuremberg - IMT - Virtual Reality - courtroom - aesthetics - presence 


\section{Introduction}

The Courtroom 6oo Project encapsulates the development of a 3D interactive, headset-based Virtual Reality (VR) experience of the Nuremberg Trials, set in a virtual rendition of its original scene in the robust, historical building of the Palace of Justice in Nuremberg. ${ }^{1}$ Courtroom 6oo remains today one of the major material referents in the histories of international law, representing the symbolic birthplace of International Criminal Law (ICL). The glorification of its history and its history-writing capacity is not an uncommon practice in the relatively young field of ICL. ${ }^{2}$ Having a building that physically carries the traces of the past supports the aspiration to affirm, show, commemorate and make tangible its place in history. The attraction of the Court moreover is such that the building has come to offer, as we would say, a legal sightseeing point of interest. ${ }^{3}$ In this piece, we pick up on the Courtroom 6oo Project as capitalising on the interest with visiting the place 'where it happened', and pushing the boundaries of experiencing 'being there', where it happened.

Interestingly, though at least some of the concern with prosecuting aged defendants seems to lie with defendants not quite looking the part, this is not how aging in courtrooms appears to be received. Where the theatric characteristics of international criminal proceedings are drawn out, it is alleged that ' $[t]$ o have performative depth and emotive resonance, stage productions need compelling and convincing actors'. ${ }^{4}$ And, we would add, they need a set to fit the bill. Yet whereas aging in defendants is variously accompanied by epithets as frail, infirm, weak, and wilting, a historic court building comes out

1 J. McBride, Reviving Holocaust History with Virtual Reality, available online at today.uconn. edu/2019/o1/reviving-holocaust-history-virtual-reality/\# (accessed 13 April 2021); Greenhouse Studios, Courtroom 6oo: A Virtual Reality Encounter with Evidence of the Holocaust, available online at greenhousestudios.uconn.edu/projects/courtroom-6oo/ (accessed 13 April 2021); Greenhouse Studios UConn, A Virtual Reality Encounter with Evidence of the Holocaust, presentation of the project as part of 'The Digitalisation of Memory: Technology-PossibilitiesBoundaries' seminar at The Falstad Centre and POLIN Museum of the History of the Polish Jews, 2 March 2021, available online at youtu.be/QAtibihA2XU (accessed 27 July 2021).

2 S. Stolk, 'The Record on Which History Will Judge Us Tomorrow: Auto-History in the Opening Statements of International Criminal Trials', 28 Leiden Journal of International Law (2015) 993-1012; C. Schwöbel-Patel, Marketing Global Justice: The Political Economy of International Criminal Law (Cambridge University Press, Cambridge, 2021); B. Sander, 'History on trial: historical narrative pluralism within and beyond international criminal courts', 67(3) International \& Comparative Law Quarterly (2018) 547-576.

3 S. Stolk and R. Vos, 'International Legal Sightseeing', 33(1) Leiden Journal of International Law (2020) $1-11$.

4 J. Sedgwick, 'An Age-Old Question: Optical (A)llusions, (In)Decency, and (In)Justice in the Trial of Japanese War Criminals', in this issue, pp. 86-107. 
the other end with allusions to eminence, authenticity, tradition, history and gravitas. ${ }^{5}$ This tendency finds expression in the Courtroom 6oo Project, which seeks for example to make historic archival material accessible and relevant to a wide audience. This should be achieved through the (serious game) design of a 'personal encounter' set in Courtroom 6oo. The narrative will be principally based on primary source documents from the International Military Tribunal (Імт), starting with the Iмт papers of executive trial counsel Thomas J. Dodd. The Project seeks to emphasise that history is not static but rather a 'product of its time'. The historical Courtroom as the key locus of interaction performs an important function in shaping the learners' experience of time, timelessness, and the dynamic nature of memory and remembering. It is not the virtual equivalent of a museum visit but an attempt to immerse the audience in history through time travel and a first-person experience.

The Courtroom 6oo Project is being undertaken by Greenhouse Studios, a research unit at the University of Connecticut, in collaboration with, amongst others, the Nuremberg Trials Memorial ('Memorium Nürnberger Prozesse') and the United States Holocaust Memorial Museum. ${ }^{6}$ The primary intended audience for the VR experience is adult learners in the age group 18 to 35 years old living in the US. This age group shows an enduring interest in wwII yet a decline in Holocaust history awareness. The Project aims to particularly stimulate this age group to engage with this complex history. ${ }^{7}$ The Project was initiated before the global pandemic and is at the time of writing still in its development phase, but it seems that plans for the vR Project were uncannily timely in light of the world-wide experimentation with ways of substituting real-time, in-person

5 On the architecture of courthouses, see L. Mulcahy and E. Rowden, The Democratic Courthouse: A Modern History of Design, Due Process and Dignity (Routledge, Abingdon, 2019); M. Bak McKenna, 'Designing for International Law: The Architecture of International Organizations 1922-1952', 34(1) Leiden Journal of International Law (2021) 1-22; R. Vos and S. Stolk, 'Law in Concrete: Institutional Architecture in Brussels and The Hague', 14(1) Law and Humanities (2020) 57-82; J. Simon and N. Temple (eds.), Architecture and Justice: Judicial Meanings in the Public Realm (Routledge, Abingdon, 2013).

6 McBride, supra note 1; Greenhouse Studios, supra note 1. In a simultaneous initiative, the Descendants Media Group is developing another Courtroom 6oo project, which aims to take visitors on 'an immersive journey inside the Nuremberg trials'. When finished, the platform should include an extensive set of learning modules, teacher resources and a virtual museum with augmented reality elements and $3 \mathrm{D}$-environments. This project too focuses on young audiences: 'Our future-proof, digital storytelling strategy will teach high school students and global history enthusiasts about the lessons of Nuremberg.' See www.courtroom6oo.org (accessed 13 April 2021).

7 Project proposal, 'Courtroom 6oo: An Educational Virtual Reality Encounter with the History and Legacies of the Nuremberg Trials', on file with authors. 
engagement. ${ }^{8}$ Yet as we have moved so many of our encounters into the virtual, we have also been reminded of the importance of 'being there'. There is perhaps a new-found appreciation of the value of touching the material and feeling the gravity that lingers in Courtroom 6oo as you are there, and an awareness that these do not persist so easily virtually. What will the Courtroom 600 Project do with the experience and presentation of international (criminal) law, international criminal trials and their history for those who enter its virtual reality? And more generally, what does it mean to resort to 'future' technologies in order to make sense of history, particularly in the context of ICL and the aesthetics of aging?

Admittedly, our initial gut-reaction to the prospect of a vR experience of Courtroom 6oo was one of great apprehension. This response we have found echoed among colleagues (mostly of a different age than the Project's target audience) in informal conversations as well as in reactions to our presentation in the context of this project on the visualities and aesthetics of prosecuting aged defendants. ${ }^{9}$ Somehow, defendants should not be old, and a court should not be hip. Such initial responses are perhaps linked to larger concerns with a spectacularisation of ICL and trials or perhaps to the preoccupation of the field with its own solemnity. ${ }^{10}$ Gradually, however, when thinking through contemplating the implications of a virtual reality experience of the Nuremberg Trials, and notably after speaking with two of the project leaders, we have become intrigued by the dilemmas that come into play here. For example, what does it mean to 'be there' virtually? More specifically, when do the possibilities of VR

8 The term 'virtual reality' is used in this article as an umbrella term for different types of extended reality tools such as VR, augmented reality, $3 \mathrm{D}$ environments, serious gaming etc. More on the distinction, see, e.g., L. Freina and M. Ott, 'A literature review on immersive virtual reality in education: state of the art and perspectives', 1(133) The International Scientific Conference ELearning and Software for Education (2015) 133-141.

9 The Courtroom 6oo Project leaders shared how they too often met these same reactions. In their experience putting the terms game, game-based and Nazi, crimes against humanity, and Holocaust in proximity to each other raises (rightfully), concerns that the events will be trivialized and/or misrepresented. Though they have seen, over the past 3 to 4 years, a greater degree of openness to utilizing new media than was previously the case. They note that things have shifted—somewhat.

10 C. Schwöbel-Patel, 'Spectacle in International Criminal Law: The Fundraising Image of Victimhood', 4(2) London Review of International Law (2016) 247-274; W. Werner, 'Justice on Screen: A Study on Four Advocacy Documentaries on the ICC', 29 Leiden Journal of International Law (2016) 1043-106o; S. Stolk, The Opening Statement in International Criminal Trials: A Solemn Tale of Horror (Routledge, Abingdon, 2021); I. Tallgren, 'Come and see? The power of images and international criminal justice', 17 (2) International Criminal Law Review (2017) $259-28$ o. 
technology carry over into a risk of a participant being there 'too much'? And, how does the virtual rendering of the Courtroom challenge the understanding of Courtroom 6oo as 'forum' or 'new fora', that is: 'as site wherein the results of the investigation conducted in 'the field' are presented and contested." ${ }^{11}$ As by novel means a historic representation of a trial becomes potentially accessible to anyone, anywhere, what is the user watching and even participating in? From the outset, we want to make clear that the aim of this chapter is not to evaluate VR experiences or this particular project in normative terms nor to make any recommendations with regard to the use of VR in ICL. We are analysing this Project to distill the practical, ethical and philosophical dilemmas and opportunities that arise when designing a VR experience in the realm of ICL. Moreover, we use this as a case study to further develop our thinking on the importance of 'being there', which we have observed in our broader research to the encounter between international (criminal) law and its audiences.

The two realities of Courtroom 6oo, analogue and virtual, embody the life and the event that once was. In each their own way, they bring it back to life, inviting the past into the present. We are curious as to how the aesthetic of the old - the historic Courtroom, the yellowed documents, the creaking voice of Robert Jackson, black and white photographs and footage-is presented as authentic and attractive, both in museological conservation on site and in using a catchy, young technology for outreach. Moreover, we are interested in the eclectic aesthetics of both the virtual and physical Courtroom 6oo and how they create a space for informal civil society as well as for individual encounters with the past.

In this contribution, we first discuss a visit to the physical Courtroom 600 and then contrast this with the experience of the virtual Courtroom 6oo. We draw attention to how (re)experiencing the past is central to both, if through different means and with different implications for what it means to 'be there' where or as it happened. (Re)experiencing the past means collapsing past and present, yet without conflating time so as to preserve historical integrity and to gain an understanding of the meaning of the past for the present. Perhaps counter-intuitively at first, making the history of the IMT attractive and accessible to a young audience turns around placing restraint over the near infinite possibilities (VR) technology holds.

11 E. Weizman, 'Introduction: Forensis', in E. Weizman (ed.), Forensis: The Architecture of Public Truth (Sternberg Press, Berlin, 2014), pp. 9-34, as cited in S. Benzaquen-Gautier, “'Crush! Crush! Crush!": Towards a Finished Story of Pol Pot's Trial and Death?', in this issue, pp. 261-278. 


\section{2 Visiting Courtroom 6oo-Being there Where it Happened}

A visit to the physical exhibition Memorium Nürnberger Prozesse in the Palace of Justice in Nuremberg is 'international legal sightseeing' par excellence, amounting to a 'spectacular yet trivial manifestation of international law and its partly anticipated, partly unpredictable encounter with a plurality of audiences.' ${ }^{12}$ Courtroom 600 pauses at a grave historical moment in international (criminal) law. At the same time, as a tourist sight it cannot get away from the trivialities of museum reality, such as signposting and the logistics of an (audio)tour. Adding to the complex interplay of past and present is the fact that Courtroom 6oo has functioned as an active Court until March 2020. This means that for long, visitors could only access the site when the Court was not in session. ${ }^{13}$ Currently, preparations are underway for a new stage in the life of Courtroom 6oo, which is no longer an active Court and simultaneous parttime museum, but a full-time memorial. Meanwhile, pending the transition as well as Covid restrictions, the Memorium Nürnberger Prozesse has moved its exhibition and Courtroom tour online. ${ }^{14}$ These particular initiatives fit in well with current trends and pressure to increase and accelerate the virtual access to (international) law and Courts-for touristic and judicial purposes alike. ${ }^{15}$

Memorials and museums have a distinct role in guarding and signifying history and memory, specifically with regard to war and conflict. ${ }^{16}$ This has been explored in depth in the fields of for example museum studies, transitional

Stolk and Vos, supra note 3 and www.legalsightseeing.org. See also S. Matsiko, 'Optics, Aged Witnesses and Aged Defendants: Habré at the Extraordinary African Chambers', in this issue, pp. 244-26o; B. Holá and T. Bouwknegt, “Jáchymov's Hell”: Trekking in the Memoryscape of Czechoslovakia's Communist Forced Labour Camps', this issue. pp. 328-346.

13 This combined co-existence of past and present neatly illustrates the everyday spectacular that characterises legal sightseeing. International courthouses as tourist destinations regularly have this dual function: the International Criminal Court and International Court of Justice both accommodate visitors with exhibitions and guided tours, but are also active courts.

14 For information about the Courtroom 6oo permanent exhibition, see Museums Nuernberg, https://museums.nuernberg.de/memorium-nuremberg-trials/permanent-exhibition/ courtroom-6oo/ (accessed 30 March 2021). For the virtual tour, see Museums Nuernberg, https://museen.nuernberg.de/memorium-nuernberger-prozesse/dauerausstellung/ virtuelle-tour-saal-6oo/ (accessed 30 March 2021).

15 Elsewhere in this issue, Caroline Davidson notes how in Chile, Constitutional Court hearings (unlike the trials of human rights defendants) are available on YouTube: C. Davidson, 'Of Old Men, Country Clubs, and Atrocities-The Visualities and Externalities of Detaining Elderly Human Rights Violators in Chile', in this issue, pp. 142-165.

16 A. Witcomb, 'Remembering the dead by affecting the living: the case of a miniature model of Treblinka', in S. Dudley (ed.), Museum Materialities: Objects, Engagements, Interpretations (Routledge, Abingdon, 2010), pp. 39-52. 
justice and memory law. ${ }^{17}$ Examples of sites of (dark) tourism ${ }^{18}$ are the Museum of Genocide and Killing Fields in Cambodia, ${ }^{19}$ the Nanjing Massacre Memorial Hall, ${ }^{20}$ and the Apartheid Museum in Johannesburg, ${ }^{21}$ among others. The grounds and buildings of the Auschwitz-Birkenau camps have been labelled as belonging to a sub-category of 'Holocaust tourism,', 22 which too may be applicable to Courtroom 6oo.

17 See, e.g., J. Winter, 'Museums and the Representation of War', 10(3) Museum and Society (2012) 150-163; A. Alba, The Holocaust Memorial Museum: Sacred Secular Space (Palgrave MacMillan, London, 2015); J. Apsel, Introducing Peace Museums (Routledge, Abingdon, 2015); A. Milosevic, 'Remembering The Present: Dealing With The Memories Of Terrorism In Europe', 8 Journal of Terrorism Research (2017) 44-61; U. Belavusau and A. GliszczyńskaGrabias, Memory: Towards Legal Governance of History (Cambridge University Press, Cambridge, 2017); J. Clark, 'Reconciliation through Remembrance? War Memorials and the Victims of Vukovar', 7 International Journal of Transitional Justice (2013) 116-135.

'Dark tourism' is a contested term, but a useful definition for our purpose is: 'visitations to places where tragedies or historically noteworthy death have occurred and that continue to impact our lives' by P. Tarlow, 'Dark Tourism: The Appealing "Dark Side" of Tourism and More', in M. Novelli (ed.), Niche Tourism - Contemporary Issues, Trends and Cases (Routledge, Abingdon, 2005), p. 48. See also J. Lennon and M. Foley, Dark Tourism: The Attraction of Death and Disaster (Continuum, London, 200o); P. Stone, 'A Dark Tourism Spectrum: Towards A Typology of Death and Macabre Related Tourist Sites, Attractions And Exhibitions', 54(2) Tourism (2006) 145-16o. For discussion on this sensitive term, see, e.g., D. Light, 'Progress In Dark Tourism And Thanatourism Research: An Uneasy Relationship With Heritage Tourism', 61 Tourism Management (2017) 275-301; G. Dann and A. Seaton (eds.), Slavery, Contested Heritage and Thanatourism (Routledge, Abingdon, 2001); J. Henderson, 'War as a tourist attraction: the case of Vietnam', 2 International Journal of Tourism Research (2000) 269-28o.

19 M. Elander, 'Images of Victims: The EcCC and the Cambodian Genocide Museum', in D. Manderson (ed.), Law and the Visual: Representations, Technologies, and Critique (University of Toronto Press, Toronto, ON, 2018), chapter 9; R. Hughes, 'Dutiful Tourism: Encountering the Cambodian Genocide', 49 Asia Pacific Viewpoint (2008) 318-330; J. Henderson, 'Communism, heritage and Tourism in East Asia', 13 International Journal of Heritage Studies (2007) 240-254. For a discussion of artistic interventions regarding the trial and death of Pol Pot see Benzaquen-Gautier supra note 11. Benzaquen-Gautier also refers to George Wright in pointing out an 'unexpected (..) object of tourist fascination', Bezaquen-Gautier, supra note 11, p. 278; Wright: 'A group of unidentified Cambodian officials tour the cremation site of Khmer Rouge leader Pol Pot', G. Wright, 'Patriot, lucky spirit, villain: Pol Pot remembered', The Diplomat (13 April 2018), available online at www.thediplomat.com/2018/o4/patriotlucky-spirit-villain-pol-pot-remembered/ (accessed 13 April 2021).

20 K. Denton, 'Exhibiting the Past: China's Nanjing Massacre Memorial Museum', 12 The AsiaPacific Journal (2014) 1-15.

21 D. Newbury, "Lest We Forget": Photography And The Presentation Of History At The Apartheid Museum, Gold Reef City, And The Hector Pieterson Museum, Soweto', 4 Visual Communication (2005) 259-295.

22 See also the typology of Stone, supra note 18. For a comparative study of the representation of the Holocaust in memorials and museum/memorials country by country: J. Young, Holocaust Memorials and Meaning: the texture of memory (Yale University Press, New Haven, CT, 1993). 
The city of Nuremberg has an ambivalent past as both a significant city in Nazi Germany and the place where the Nazi leadership faced trial after the war, the latter being emphasised in the memorial exhibition at the physical site. ${ }^{23}$ The Courthouse as a memorial highlights the role of law to speak to power, and of the power of law to bring criminals to justice. As an audience, being in the actual Courtroom can almost make you 'feel' this power. Visiting a place with such a grave history evokes both feelings of interest and estrangement. On the one hand it turns an abstract, but famous place into a real, physical place, yet on the other hand it alters or even breaks down the imagination. ${ }^{24}$

The current building speaks to its history in different ways. The Courthouse itself has been renovated and reorganised, ${ }^{25}$ but the original atmosphere is preserved through the exhibition of iconic artifacts - the benches of the accused and the original docket - as well as the display of historical photos, videos and audio clips and media portals, which 'allows individuals to deepen their knowledge of the Nuremberg Trials.' ${ }^{26}$ The exhibition on the third floor of the Palace of Justice allows visitors to 're-experience' being in the audience in $1945 .{ }^{27}$ During a visit, one thus both experiences the Courtroom as it is through a Courtroom tour and re-experiences the Courtroom as it once was through the exhibition on the third floor.

It is interesting to note the Museum's exhibition concept:

A conscious decision was made to display few if any artifacts, in accordance with the documentary nature of the exhibition. Instead, the exhibition seeks to provide an objective description of the events that transpired here, so that visitors can form their own 'judgment' of the prosecution of Nazi crimes. ${ }^{28}$

23 On the complicated history of Nuremberg, see S. Macdonald, Difficult Heritage: Negotiating The Nazi Past In Nuremberg And Beyond (Routledge, Abingdon, 2010).

24 See, e.g., V. Posada Villada and D. Kramer, 'Courtroom 6oo and Memorium Nürnberger Prozesse', Legal Sightseeing (15 May 2019), available online at www.legalsightseeing. org/2019/05/15/legal-sightseeing-nuremberg/ (accessed 14 April 2021). Posada and Kramer note that ' $[\mathrm{a}] \mathrm{s}$ soon as one goes inside Courtroom 6oo, it is hard to imagine that the Nuremberg Trials took place in the same place.' A brief history of Courtroom 600 can be found at the website of the memorial: museums.nuernberg.de/memorium-nurembergtrials/permanent-exhibition/courtroom-6oo (accessed 14 April 2021). Memorial website, ibid.

26 Ibid.

27 Posada Villada and Kramer, supra note 24.

28 Memorial website, supra note 24. 
In the exhibition, emphasis is placed on the original trial video and audio clips on display. ${ }^{29}$ Whether objectivity in a curated exhibition is actually possible remains questionable, ${ }^{30}$ yet in any case, a 'documentary' approach seems to be quite different from the philosophy underpinning VR experiences and their emphasis on immersion, narrative and connection. The VR experience sees the re-creation of artifacts as one of its added values to go beyond the mere display of artifacts that have stood the test of time, unburdened by a museum's dual function of displaying but also conserving these artifacts - for example, by placing them behind glass. Even though the museum actively limited the display of artifacts, it is arguably the presence, authenticity and tangibility of the original artifacts that makes Courtroom 6oo unique in comparison to a VR or other exhibition or (photo)archive of the IMT.

The exhibition staged at the location of the IMT also invites for further reflection on the power of buildings as iconic sites ${ }^{31}$ and practices of re-appropriation of current or former legal sites, ${ }^{32}$ as well as the expectations that are held for these buildings. ${ }^{33}$ These places advertise themselves by appealing to their legal histories. The privilege of accessing these otherwise closed-off sites attracts, even when the original occupants have left a long time ago. ${ }^{34}$ Visitors are drawn to the place 'where once was'. The building that remains bears testimony to that past.

29 The Courtroom 6oo Project leaders relayed anecdotally how the past director indicated that the museum lacked artifacts in its collection and how this presented a challenge to the design team. She had been working with the United States Holocaust Memorial Museum, for example, on the possibility of loans of Імт items held in their collections, but not on display in the US.

30 See, e.g., T. Luke, Museum Politics: Power Plays at the Exhibition (University of Minnesota Press, Minneapolis, MN, 2002); D. Fleming, 'Museums, Human Rights, Contested Histories and Excluded Communities', 67 Museum International (2015) 116-124; H.J. Evans, L. Nicolaisen, S. Tougaard and M. Achiam, 'Museums beyond neutrality', 29(2) Nordisk Museologi (2020) 19-25. See also the 'Museums Are Not Neutral' movement, www.museumsarenotneutral.com (accessed 14 April 2021).

$31 \quad$ Bak McKenna, supra note 5; Vos and Stolk, supra note 5.

32 E.g., the former American Embassy in The Hague (http://www.onzeambassade.nl/) and the Charles Street Jail in Boston, now called the Liberty Hotel.

33 It is interesting to compare here the expectations held of this different iconic building in legal proceedings: the prison. On the impact on transitional justice of the image of Punta Peuco prison in Chile as "Country Club Prison" for human rights violators, see Davidson, supra note 15 .

34 R. Vos and W. Werner, 'Offices', 28(1) New Perspectives (2020) 44-50. 
There are different stakes in the attempt to create or preserve a site where the past can be re-experienced; for example, we can identify an emotional logic, an educational logic, a commercial logic but also a logic of repetition. Manifestations of repetition, re-enactment, and recalling are quite common in international law in general, as a way to link the present to the past and to simultaneously solidify and update certain meanings. ${ }^{35}$ With any repetition, these meanings also alter. Visitors experience, or rather re-experience, the historical power and spectacle of international law, which may affect their imaginary of contemporary international law. But by visiting, seeing, touching the place, this abstract fantasy also unavoidably changes and simultaneously becomes something concrete and tangible. The meaning of international law is transformed by its re-experience.

\section{Courtroom 600 in VR-Being there as it Happens}

The development of a virtual visit to Courtroom 6oo further challenges our thinking on what it means to 'be there'. Just like a 'real' visit, a virtual visit aims to create a sense that one is actually 'there', by making the past tangible. ${ }^{36} \mathrm{~A}$ visit to the physical Court enhances the sense of presence by literally enabling audiences to be there where it happened and to see the actual artifacts involved at that time. A virtual reality experience can approach this through a virtual spatial immersion and through a virtual rendering of artifacts that can then also be 'handled' in the VR experience.

VR can also do more: it can let the participant 'travel through time' to relive the events that took place. The near endless possibilities this entails, also raise pertinent dilemmas. Notably in the context of Courtroom 6oo, for all the fascination with and the desire for 'the original', what if a participant in the VR experience cannot deal with the original? When is 'being there' too much?37 Designing an immersive VR environment includes not only thinking about the technical aspects, narrative and physical setting (when is it experienced,

35 W. Werner, 'Recall it again, Sam. Practices of Repetition in the Security Council', 86 Nordic Journal of International Law (2017) 151-169.

36 See Freina and Ott, supra note 8, p. 2, who note: 'Spatial immersion occurs when a player feels the simulated world is perceptually convincing, it looks "authentic" and "real" and the player feels that he or she actually is "there".'

37 Conversation with Courtroom 6oo VR project leaders, 12 January 2021, report on file with authors. 
where, with whom), but also the 'cultural, haptic, organisation, social, logistic, historical and multifaceted perspectives of reality. ${ }^{38}$

With this in mind, we were given the chance of a conversation with the leaders of the Courtroom 6oo Project described in the introduction. Our initial apprehension and the ethical and practical dilemmas we anticipated were echoed and nuanced by the project leaders who were truly generous in telling us about their journey. As they emphasised, the Project not only seeks to create a VR experience but is also a research project into new ways of understanding and conveying history. VR experiences offer potentially more intuitive ways of learning and encapsulate different ways of teaching information as and when its application comes in view. In this section we will describe the main ideas, struggles and thoughts of the project leaders that we discussed in light of our search for the meaning of 'being there' in international criminal courtrooms and their vR equivalent.

In virtual reality design, two main approaches to immersion can be distinguished: immersion as (1) 'an objective characteristic of the technical system features and affordances' 39 and (2) 'a psychological state characterized by one's perceptions of presence and interaction' ${ }^{40}$ The Courtroom 6oo Project mainly aligns with the latter perspective. For the purpose of this article we use the definition of 'immersion' as formulated by Agrawal et al.:' 'a phenomenon experienced by an individual when they are in a state of deep mental involvement in which their cognitive processes (with or without sensory stimulation) cause a shift in their attentional state such that one may experience disassociation from the awareness of the physical world. ${ }^{41}$ Immersive environments can be designed with a learning objective in mind, such as the Courtroom 6oo Project, but they can also induce learning without such an objective. ${ }^{42}$

Concretely, in the design of the Courtroom 6oo Project, the player-aslearner-in the language of the Project-remains themselves, yet through a time-travel mechanism moves to (and from) the time of the Nuremberg Trials, where they assist executive trial counsel Thomas J. Dodd. In its current set-up, the VR experience uses the trial as a window into a story. The learner

38 D. Beck, L. Morgado and P. O'Shea, 'Finding the Gaps about Uses of Immersive Learning Environments: A Survey of Surveys', 26(8) Journal of Universal Computer Science (2020) 1043-1073, p. 1045 .

39 Ibid.

40 Ibid.

41 S. Agrawal, A. Simon, S. Bech, K. Bæntsen and S. Forchhammer, 'Defining Immersion: Literature Review and Implications for Research on Audiovisual Experiences', 68(6) Journal of the Audio Engineering Society (2020) 404-417, p. 407.

Beck et al., supra note 38, p. 1046. 
unlocks the history of the trial step by step, using primary source documents to point to places, people, and events that form the ingredients of the narrative. Throughout this exploration, action and context are in conversation. As discussed, the physical Nuremberg exhibition presents a complex entanglement of co-existing past and present in one space. Greenhouse Studio's VR project also plays with connecting different temporal realities in its design of a narrative that pulls original source material from different times into one narrative. In that way, 'the Courtroom 600 experience underscores that our understanding of the past is not static; rather, it is a product of its time and contexts of production, of the sources available, the sources consulted, and of the research questions asked. ${ }^{\prime 3}$ In order to protect the historical integrity of the representation of the trial, the design uses the changing architecture of the Courtroom as indicator for the learner that she has entered a different time. ${ }^{44}$

This set-up entails that, at a certain point, the learner thus steps into the Courtroom during the trial. In a realistic historical rendering this entails a sense of psychological discomfort; think of the volume and noise of the crowd, the flashes of cameras. The team shared their wish to convey the atmosphere to the learner, and equally the need to not keep the learner so fully immersed for too long as it could easily become claustrophobic. Virtual reality can stimulate 'mental absorption or intense preoccupation' with a narrative, which redefines what it is to 're-experience' or 're-live' past events, for it may affect the cognitive process differently, more intensely. ${ }^{45}$ In that sense, virtual experience can, in theory, be almost more real than an analogue recreation of the past. 'Going back in time' entails an entanglement of the worlds of the living and dead. The technology can not only help to keep history alive, or to bring the past back to life, it in a way can do the same for defendants. The project team explained how this makes it pertinent to balance immersion and distance in decisions on how to represent defendants: imagine the impact of standing as close as $3 \mathrm{ft}$ away from a Nazi war criminal. One of the decisions the team took in this regard, is to blur visualisation of defendants.

Working with a narrative in the VR experience, draws the learner in and structures their encounter. In the context of a historic trial, this however also creates a dilemma of how to avoid the danger of revising history. One of the

43 Courtroom 6oo Project, Summary of Proposal, on file with authors.

44 On the changing architecture of Courtroom 6oo, see M. Somos and M. Gostwyck-Lewis, 'A New Architecture of Justice: Dan Kiley's Design for the Nuremberg Trials', 21(1) Journal of the History of International Law (2019) 104-139. On the renovations after 1945 see also the Memorium website, https://museums.nuernberg.de/memorium-nuremberg-trials/ permanent-exhibition/courtroom-6oo/use-after-1945/ (accessed 14 April 2021).

Agrawal et al., supra note 41. 
main challenges for the UConn project in this regard has been dealing with the agency of the learner. The aim of a VR serious game cannot be to recreate, re-enact or simulate history. Nonetheless, for a serious game to work, there has to be a narrative. In a way, as noted by one of the project leaders, some elements have to be made 'unreal' to create an experience of realness. Importantly, the designers' commitment to respect history, means no different outcome than the historic outcome of the trial proceedings is possible in the VR experience. Here the decision for learners to remain themselves also recurs. In this way, no new characters are written into history, as it were. Nor does the design become an invitation for a 'role-play'. Additionally, the designers have to be cautious not to create a game that allows, even inadvertently, for Nazi glorification or misuse. Although any type of Holocaust education grapples with these ethical issues ${ }^{46}$ the degree of immersion aimed for in VR adds an extra layer of complexity.

Ideally, an immersive experience is multisensory, including touch and smell, even if most VR/serious gaming projects focus on the audiovisual realm. ${ }^{47}$ The designers of the UConn Courtroom 6oo Project were highly aware of the importance of rendering the proper feel to virtual objects, to make them more tactile. ${ }^{48}$ This could not only recreate an 'analogue experience' but also supersede it: many original trial documents have become so frail that they can now only be accessed digitally, but pulled into a VR environment they can look, move and feel like actual paper again..$^{49}$ This goes to show how the delineation between virtual and physical, or analogue, reality has become deeply nebulous.

46 On the ethics of teaching the Holocaust for children see B.J. Epstein, K. Andrews, M. Gray and A. Maws, 'Discussion Forum Inflicting Trauma: The Ethics of Writing and Teaching the Holocaust for Children', 19(1) Holocaust Studies (2013) 101-120. On the challenges of Holocaust representation in different areas see J.-M. Dreyfus and D. Langton (eds.), Writing the Holocaust: Writing History (Bloomsbury, London, 2011).

47 Freina and Ott, supra note 8, p. 2.

48 Conversation with Courtroom 6oo vR project leaders, 12 January 2021, report on file with authors.

49 The Courtroom 6oo Project leaders commented that: 'an important distinction here is that while the VR experience re-creates the courtroom, other spaces, and (one might say) the people, we are not re-creating primary source documents in the same way. Rather, these digitized materials held in online repositories are being "pulled" into the VR experience and "restored" to three-dimensionality. So, just as a researcher in the archives might hold a photo and flip it over (vs. see separate images of its front and back sides on a website) so, too, can the VR user have the sensation of holding and turning over the photo. So, digital surrogates (just as is true of all online archives/collections) vs. drawings or artistic renderings of primary sources. In essence we ask: will far future users of online archives be using 2-dimentional website interfaces or preferring to handle and inspect materials using VR?'. 
Whereas VR offers new possibilities for re-experiencing history, the particular historical trial context as the main locus of the VR environment proved to also have limits in light of the educational goals of the UConn project. The game aims at enhancing Holocaust education, yet the Iмт did not address the issue of the Holocaust as such. The game also aims to empower voices of those that have long remained unheard, such as women and Jewish resistance groups, yet the trial foregrounds the defendants. Finally, the starting point of the VR experience is to have the learner work with primary source material in an accessible way, yet trial documents are long and can be rather dull. Besides these incompatibilities between the aims and practicalities of the VR experience set in the Nuremberg Courtroom, there are further ethical issues. Most evident is the presentation of serious subject matter, in this case the prosecution of Nazi leadership, in a, be it serious, 'game' format.

To some extent, there is a potentially mediating function to a trial environment. The distance between the trial and events may actually remedy some of the ethical challenges of Holocaust education. Via the trial and documents, the grave subject matter can be conveyed more indirectly, less graphic, less spectacularised. Still, the limitations necessarily imposed by the trial format are considerable. Notably, the trial format restricts the way in which certain histories can be told. ${ }^{50}$ It almost seems as if emphasising the legal aspects of the trial would interfere with conveying the historical narrative. The aesthetics of a historical courtroom and its 'dullness' may temper a more spectacularisedand perhaps inappropriate-virtual representation of the Holocaust but it has its own complexities, on which we will reflect in the next section.

\section{The Eclectic Aesthetics of Reconvening the Past}

Introducing VR technology to learning and outreach on the historic Nuremberg Trial pushes on what it means to 'be there' to (re)experience the past. In this section we ask what the eclectic mix of aesthetics and visibilities of the VR experience of Courtroom 6oo entail. The VR experience reconvenes the past in the present and so collapses time. We wonder what insights this brings for the expectations or for what is considered appropriate around aging in courtrooms and defendants, for what becomes visible or remains invisible when

$50 \quad$ See, e.g., Stolk (2021), supra note 10; M. Drumbl, 'Staging International Law's Stories: Kapo in Jerusalem', in S. Stolk and R. Vos (eds.), International Law's Collected Stories (Palgrave Macmillan, London, 2020), pp. 37-55. 
reconvening the past, and finally what more the aesthetics of outreach may accelerate.

Although it remained active until recently, Courtroom 6oo can be regarded as an 'aged'-and certainly historic-Courtroom, embodying a remarkable past. As becomes clear in other contributions to this special issue, aging in people may invoke an imaginary of frailty. ${ }^{51}$ By contrast, the older, robust building of the Palace of Justice in Nuremberg stands for eminence, maturity and tradition. Courtroom 600 is one of the major material referents in the histories of ICL, even representing its symbolic birthplace. As such, its history and history-writing capacity have been glorified. ${ }^{22}$ Having a stately building embodying the past enhances an aspiration to affirm, show and make tangible this historic significance. The eminence of the building also lifts the maturity of ICL, it places ICL in a longer tradition and so masks ICL's relative youth.

When a VR experience reconvenes the past, it recreates a version of it by collapsing time. It is an opportunity to connect the present to the past and to visualise the elements that best fit with our expectations or preferences. One can choose to visualise the Courtroom in its original state, to revive documents that can now only be accessed in specialised — and digitised — archives, to erase the faces of defendants to avoid discomfort. The possibilities of VR for the visualisation of things, persons and sites that exist(ed) or did not exist are near endless. Yet, if one wishes to stay within the context of a historic trial, and thus to ensure ethical sensitivity and to minimise rewriting history-as are objectives of the Courtroom 6oo Project - the design choices suddenly become about what not to visualise, show, or make possible.

In light of this special issue, it is interesting to note that the Courtroom 6oo VR Project has an interest in showing the 'aging' of the Courtroom and to have the learner actively experience the passing of time. The passing of time is further emphasised by the VR's set up as a time travelling device. The collapse of time in VR does not only collapse past and present but also the time span of a trial. A process which took months is compressed into an experience that lasts only minutes, or hours at most. Both require active choices about what to show and what to leave out. As the project leaders also discovered, the slowness of a trial does not lend itself too well to a (serious) 'game' format. But what is left of the actual trial experience if the important element of time is taken out of the equation?

Opacity in a trial can be a point of ambiguous contention. Stephanie Benzaquen-Gautier in this special issue, raises pertinent questions around the

$51 \quad$ C. Fournet and M. Drumbl, 'The Visualities and Aesthetics of Prosecuting Aged Defendants', in this issue, pp. 1-21. See supra note 2. 
conditions and effects of the (non)images of the trial and death of Pol Pot.53 Through one artistic engagement with the trial, she advances the idea of the opacity of the trial as an anti-spectacle in disjunction with an imagined or desired' (international) justice trial. ${ }^{54}$ Through a second artistic commentary on the photographic images accompanying the death of Pol Pot, she draws attention to the other side of the contention: a converse 'excess of visibility'. 55 Capturing the image of the 1997 trial of Pol Pot in Anlong Veng, moreover was marked by the status quo in technological advancements at that time, as well as by the inaccessibility of Cambodia to foreign travelers (notably journalists), as Benzaquen-Gautier points out. Here, the radical possibilities - and risksof VR in reconvening the past become evident.

Strikingly, the Courtroom 6oo Project draws heavily on the different appearances through time of the Courtroom in designing the encounter with history, yet it only minimally visualises the defendants. This means that the events in Courtroom 6oo will, in the Virtual Reality, be re-experienced through an overly present building and an absence of the faces of the defendants. This alters the focus of the experience and changes the perception of the place of the defendant in the trial. Visualising the defendants is considered inappropriate, for showing their all too familiar (young!) faces in such an immersive setting may be too real, too confrontational. ${ }^{56}$ This decision stems from a wish to refrain from developing a narrative that puts the defendant center stage and to avoid a risk of (accidental) glorification or even hagiography. ${ }^{57}$ These considerations resonate with discussions in ICL and a persisting criticism on the exclusive focus of international criminal trials on the defendant, suppressing the voice of the victim..$^{58}$ On the other hand, such a choice to strip the defendants of their human features raises questions of the disputable erasure of agency and

53 Benzaquen-Gautier, supra note 11.

54 L. Gillick and P. Parreno, Le Proces de Pol Pot (Le Magasin, Grenoble, 1998); P. Ardenne, 'Le procès de Pol Pot selon Gillick and Parreno: vademecum de la non-esthétisation de l'horreur', 7-8 Visuel(s) (1999) 11-15, cited in Benzaquen-Gautier, ibid.

55 Redas Dirzys, Pol Pot Series, in Benzaquen-Gautier, ibid.

56 Especially if, as one of the Project leaders mentioned, a descendent of a Holocaust survivor enters the game.

57 Conversation with Courtroom 6oo VR project leaders, 12 January 2021, report on file with authors.

$5^{8}$ In the context of the IMT, see, e.g., Y. Danieli, 'Reappraising the Nuremberg Trials and Their Legacy: The Role of Victims in International Law', 27 Cardozo Law Review (2006) 1633-1649; S. Karstedt, 'From Absence to Presence, from Silence to Voice: Victims in International and Transitional Justice since the Nuremberg Trials', 17(1) International Review of Victimology (2010) 19-30. 
humanity for which ICL practices have also been criticised. ${ }^{59}$ Omitting the key features of a defendant's identity circumvents some of the issues with representation, expectation and agency that play a role in the wider discussion on the aesthetics of (aged) defendants but simultaneously opens up new points of discussion.

Though the Courtroom 6oo Project collapses time in order to make it possible to (re)experience the past in the present, it seeks not to conflate time. The visualisation of the defendant shows the defendant at the age they held when they stood trial. The visualisation does not show the defendants as they would have aged, standing trial in their aged appearance for acts committed in the past. This choice to collapse, but not to conflate time, preserves the integrity of the historic image. In parallel, the project leaders made the choice not to reconvene the ghosts of victims of the crimes on trial. Elsewhere in this special issue, Caroline Davidson makes the point that the visibility of defendants in criminal trial proceedings stands in contrast with the relative invisibility of most victims. ${ }^{60}$ VR technology makes it possible, at least in theory, to visualise victims as part of the trial proceedings.

Across contributions to this special issue, the (very) elderly presence of defendants is cause of concern. In a way, aged defendants lend inappropriate visualisations because they are not real enough: their faces do not seem to belong to the person who is alleged to have perpetrated horrible crimes in the past. Yet, as James Sedgwick points out in this special issue with regards to Nuremberg's contemporary Tokyo Trial, even when trials followed events closely in time, the appearance of defendants did not meet everyone's expectations. ${ }^{61} \mathrm{~A}$ result, at least in part, Sedgwick suggests, of the middle age typical of officials higher up the bureaucratic hierarchy. ${ }^{62}$ Yet what, we might ask, does one imagine a perpetrator of war crimes to look like? The distance invoked by seeing the actual faces of (aged) defendants can be too much: it interferes with our ability to travel back in time in our own minds. Whereas an aging building can align with our imagined ideal trial, an aging defendant is disruptive and destabilises our experience of the 'real' past. In the case of the VR experience, a certain distance needs to be preserved to make the experience digestible: there are limits to how close-up we want to be when we are there. The choice

59 See, e.g., S. Stolk, 'A Sophisticated Beast? On the Construction of an 'Ideal' Perpetrator in the Opening Statements of International Criminal Trials', 29(3) European Journal of International Law (2018) 677-701.

6o Davidson, supra note 15 .

61 Sedgwick, supra note 4.

$62 \quad$ Ibid. 
of the Courtroom 6oo Project to blur, to leave out to a large extent detailed representation of defendants, conserves this distance.

The objective of the Courtroom 6oo VR project is to convey that history is not static. In trials, the opposite seems to be true. The discomfort with aging defendants may be related to a wish to preserve the past and to judge what happened in the past without knowledge of the future and without a view to the transformation of people brought about by the passing of time. A courtroom almost needs to function as a time capsule that takes the participants back to the past, agnostic of the present. The aged appearance of a defendant does not cooperate with that fiction. Elsewhere in this special issue, the 'unusual' trial of Bruno Dey is discussed, in which a former ss guard at the concentration camp Stutthof stood trial at 92 years old for acts committed as a 17 and 18 year old. ${ }^{63}$ Moritz Vormbaum alludes there to the importance attached by the judge to general contemporary witnesses accounts in a way perhaps more typically associated with practices of remembrance and commemoration. 'We listened to them and we understood' he cites the judge. We are reminded here of the importance of survivors' testimonies for the commemoration of mass atrocities and the in many ways complicated holding on to the last survivors to tell their story. When in time only the stories remain, VR can do what trials cannot: travel back not only in words, but also visually. Whether and how at that time this will be deemed desirable remains a question. Remarkably, the developers of the Courtroom VR experience do not strive for an agnostic history, they instead emphasise the traveling itself: to understand the way in which the present affects our view of the past.

\section{5 \\ Conclusion}

In multiple ways, the Courtroom 6oo Project exposes ICL's complicated relationship with time, history and remembrance.$^{64}$ Reviewing initial reactions to seeing either an IMT VR experience or an aged defendant in an international courtroom reveals something similar about the expectations held for war crime trials. Trials are not hip, defendants are not old. There is a hesitation

63 M. Vormbaum, 'The 'Unusual' Trial of Former Concentration Camp Guard Bruno Dey', in this issue, pp. 225-243, refers to: Regional Court Hamburg, Judgment of 23 July 2020 - 617 Ks 10/19 jug.

64 For an interesting analysis on ICL's complicated temporalities, see C. Biddolph, 'Queering temporalities of international criminal justice: Srebrenica remembrance and the International Criminal Tribunal for the former Yugoslavia (ICTY)', 29(3) Griffith Law Review (2020) 401-424. See also supra note 17. 
to welcome a platform associated with entertainment and games to Holocaust education. There is a discomfort in being confronted with the frail and perhaps sympathetic or even funny appearance of an aged defendant. Both images impair an expectation of the seriousness and gravity of dealing with unspeakable suffering.

Technology will come to bear on ICL. In that exchange, things will inevitably be both lost and gained. This development will likely not be confined to the trial proceedings only, but will also and notably transform outreach activities of courts. As mentioned, the analogue Courtroom 6oo currently offers a digitised visit to its exhibition on its third floor as well as a digitised Courtroom tour, they also have a Facebook page, they develop web-content on the role of women at the Nuremberg Trial, and they are currently involved in the production of another serious game set in Nuremberg in $1934 .{ }^{65}$ It is no longer unusual that in making the history of international (criminal) law attractive and accessible to a broader audience of various ages alternative media and art are resorted to. This resort is attractive to courts too in presenting themselves to 'the public', as visual media offers representative possibilities that do not exist in law. In between the possibilities of art and international law, we find the VR Courtroom 6oo Project, balancing the divide between being able to do more and not wishing to do too much. Both the virtual and analogue Courtroom 6oo confine the experience of 'being there' through a conservative understanding of what a trial is and what a defendant looks like. This conservatism fits neatly within a conserved Courtroom that preserves a sense of distance at all times, and yet brings us just close enough.

The challenge of presenting a dynamic past, allowing for ownership and interpretation in the present without it being 'rewritten', seems an irresolvable conundrum. Every minor decision taken in the design of the VR environment and the construction of the narrative affects the kind of history it produces. Other constraints are enforced by ethical considerations and the wish to represent a story that is factually accurate. A trial format then further limits the construction of history as it brings along its own set of (narrow) representational

65 See Facebook account of Memorium Nürnberger Prozesse, available online at www. facebook.com/MemoriumNuernbergerProzesse/ (accessed 14 April 2021); see also Frauen in den Nürnberger Prozessen: Interview mit Rebecca Wei $\beta$, audio file on the Memorium website, available online at https://museen.nuernberg.de/memorium-nuernbergerprozesse/angebote/digitales-angebot/frauen-in-nuernberger-prozessen/?pk_campaign= teaserdigital\&pk_kwd=interview_weiss; Museen der stadt Nürnberg Blog, Behind the Scenes - Nuremberg '34, museenblog-nuernberg.de/2021/o2/11/serious-game-fuer-dasdokuzentrum/ (accessed 14 April 2021). 
practices. ${ }^{66}$ Whereas the collapse of time allowed for in VR can enable a more dynamic representation of Holocaust history, the use of the courtroom as a static factor throughout time - putting its physical transformation aside- has the potential of rendering international criminal law an oddly a-historical phenomenon. This again resembles the tension between the preference for trials to operate agnostic to history, and the disruptive aesthetics of an aged defendant.

We increasingly spend our time in virtual or hybrid spaces. Inevitably, this blended existence will affect the way in which VR develops and how we experience and evaluate it. The possibility to collapse time and space in a VR environment opens up new ways of conceptualising and 'being there', and indeed alters the meaning of 'being there' altogether. For (international) criminal trials specifically, its public appearance and reach is a crucial feature. This ideal of the democratic courtroom ${ }^{67}$ materialises in public galleries and more recently in livestreams or publicly available recordings. Moreover, the emphasis on outreach via different physical and virtual outreach activities serves different kinds of audiences. One can envision VR becoming another tool in that toolbox. VR offers endless opportunities for participation and observation. It allows audiences to move down from the public gallery into the actual courtroom and experience a trial from up close. It opens up new ways of imaging the public function of law. Or, conversely, it can turn into another way of confirming and reproducing ICLs traditional boundaries and conservative hierarchies. In any case, initiatives such as the Courtroom 6oo Project invite us to rethink the aesthetics of international criminal trials and push us to look beyond what it should look like to start imagining what it could look like. It evidences how 'being there' is shaped through—well—actually being there, whether physically or virtually.

66 On the discussion around ICL's historical function, see, e.g., B. Sander, 'Unveiling the Historical Function of International Criminal Courts: Between Adjudicative and Sociopolitical Justice', 12(2) International Journal of Transitional Justice (2018) 334-355.

67 J. Resnik and D. Curtis, Representing justice: Invention, controversy, and rights in city-states and democratic courtrooms (Yale University Press, New Haven, CT, 2011). 